\title{
Is corporate governance of private equity targets more effective for risk mitigation?
}

\author{
Vladimiro Marini $^{1} \mathbb{D} \cdot$ Massimo Caratelli $^{2} \cdot$ Gian Paolo Stella $^{2} \cdot$ Ilaria Barbaraci ${ }^{3}$
}

Accepted: 19 March 2021 / Published online: 23 April 2021

(c) The Author(s) 2021

\begin{abstract}
Private equity is a source of finance and a governance device characterised by active monitoring through sponsors that intervene in targets' corporate governance. As sponsors are skilled and motivated acquirors, we investigated whether corporate governance mechanisms mitigate leveraged targets' risk of financial distress differently compared to non-acquired companies through the lenses of agency theory and resource-based theories. We found that targets and non-acquired companies are not significantly different in terms of corporate governance features, but sponsors are skilled enough to choose corporate governance members to mitigate risk more, especially when boards are smaller, have busier industry expert directors, and mandate execution to more managers. These results can be useful to targets, targets' investors and lenders, and policymakers.
\end{abstract}

Keywords Private equity $\cdot$ Corporate governance $\cdot$ Board of directors $\cdot$ Risk of financial distress

JEL classification $\mathrm{G} 23 \cdot \mathrm{G} 34$

\section{Introduction}

Private equity sponsors (hereafter sponsors) are active investors that lend funds and improve the performance and the governance of their targets (Cornelli \& Karakaş, 2008; Meuleman et al., 2014; Nikoskelainen \& Wright, 2007). As majority owners, they have strong incentives to monitor rather than diffuse ownership structures, and they therefore typically intervene directly in targets' corporate governance such

Vladimiro Marini

vladimiro.marini@uniroma2.it

1 University of Rome “Tor Vergata”, Via Columbia 2, 00133 Rome, Italy

2 RomaTre University, Via Silvio D’Amico 77, 00145 Rome, Italy

3 Bologna, Italy 
as by occupying board seats. Sponsors also use considerable volumes of borrowed funds to discipline management to efficiently use free cash flows (Jensen \& Meckling, 1976). Thus, the unique ownership and financial structures imply a distinctive and effective governance structure (Cumming et al., 2007). Sponsors as well as management are incentivised to generate returns to both repay creditors and remunerate stakeholders. Firstly, sponsors operate in the opaque and competitive buyout market; as such, their reputation mostly derives from performance. Reputation then becomes the main determinant of subsequent funding rounds. As a result, not only are sponsors particularly averse to the event of a target's corporate default, they are also inclined to improve its return generation to repay their funders (e.g. Kaplan \& Sensoy, 2014; Korteweg and Sorensen 2017). Secondly, managers are interested in maintaining their position and are therefore likewise averse to default in order to keep their job in the short term and inclined to generate a strong performance to keep their job in the medium term (e.g. Bloom et al., 2015).

In short, the corporate governance mechanisms introduced by sponsors operate within highly leveraged targets, the return generations of which are crucial to service the debt necessary for a successful private equity-backed buyout. Moreover, low risk for financial distress is necessary for transaction's success but insufficient because the utility functions of sponsors and managers include strong performance not only to repay the target's creditors but also to properly fulfil funders' expectations, protect their reputation in the private equity market, and preserve their position in the medium term.

Given that sponsors and managers (and, indirectly, investors) are interested in making leveraged deals successful, it is important to investigate whether private equity-backed targets exhibit a lower risk of financial distress than their nonacquired comparables because of better corporate governance mechanisms (Gong \& Wu, 2011; Wright et al., 2009a). Corporate governance mechanisms are focus variables because sponsors typically use corporate governance mechanisms as success levers-especially after the subprime crisis-because sponsors are highly skilled and experienced investors (Millson \& Ward, 2005). Moreover, since repaying creditors is only the minimum goal of sponsors, the risk indicator should not be focused only on bankruptcy-for example, with a dummy discriminating between bankruptcy and survival-but on a broader spectrum of outcomes. Altman's Z-Score is thus used (Altman, 1983; Altman et al., 2014) as the dependent variable in this study because it is continuous and accounts for the firm's return generation process. To our knowledge, there is only one empirical work closely related to this research problem (Meuleman et al., 2014), and so we attempt to investigate the reasons for this gap, identify pathways for future research, and contribute to filling the gap.

A well-recognised challenge of corporate governance research is the limited data availability regarding corporate governance of privately held companies (Acharya et al., 2013; Wilson \& Wright, 2013). We address this challenge by studying a hand-collected European sample of boards with highly leveraged privately-held targets (companies under private equity ownership) and non-acquired companies. Targets are mostly private in nature, and European private companies have relatively strict disclosure requirements: therefore, data collection is challenged (Acharya et al., 2013; Cornelli \& Karakaş, 2008; Cumming et al., 2007; Tykvová \& Borell, 
2012; Wilson \& Wright, 2013). The research problem is framed through the lenses of resource-based theories to understand the cruciality of targets' internal (human) resources (Barney, 1991; Leiblein, 2011; Meuleman et al., 2014). Moreover, we adopted the agency theory because it focuses on leverage, management equity stakes, and majority ownership as tools to align incentives, improve monitoring, and ultimately benefit the target (Jensen, 1993; Jensen \& Meckling, 1976). Internal (human) resources and tools identified in agency theory are typical features of private equity deals (Millson \& Ward, 2005). Other scholars who have used resourcebased theories in private equity studies (Meuleman et al., 2009, 2014) have focused on understanding the cruciality of operational improvements within the firm's production process rather than on operationalising internal (human) resources.

This study makes the following contributions. First, it investigates corporate governance mechanisms and features within private equity, which are currently underresearched (board size, industry expertise, busy directors, duality, internal auditing and remuneration sub-boards, and management) despite their importance within private equity according to the literature. Second, it provides a comprehensive picture of corporate governance intervention. Third, it complements the scarce empirical literature concerning targets' boards, the opacity of which usually constrains samples' reliability. Fourth, it identifies corporate governance mechanisms, features that sponsors promote in their leveraged targets, and the related risk implications. As sponsors use corporate governance intervention and make extensive use of leverage (which could put targets in distress), these theoretical and empirical gaps should be filled to better understand which boards mechanisms are associated with stronger functioning of targets and of companies more generally.

The paper is structured as follows: Chapter 2 focuses on the theoretical framework. Sections 2.1 and 2.2 review existing literature on risk and the governance implications of private equity ownership, and Sect. 2.3 develops the hypotheses. Chapter 3 is devoted to methodology and the sample. Chapter 4 presents and discusses the results, and Chapter 5 concludes.

\section{Theoretical framework}

The growth of private equity ${ }^{1}$ has garnered criticism for its impact on stakeholders (e.g. bondholders with increased risk, employees with layoffs and wage reductions, governments with tax advantages), resulting in increased academic scrutiny and policy discussion. During the first private equity wave, leverage and financial engineering were the main drivers of targets' risk of financial distress (Andrade \& Kaplan, 1998; Wright et al., 1996, 2009a). Hence, agency theory (Jensen, 1993; Jensen \& Meckling, 1976) was the dominant theoretical framework in private equity literature because it emphasises the role of (1) leverage in disciplining managers to

\footnotetext{
1 Besides the enormous growth in volume of the Asia-Pacific private equity market $(+74 \%$ in $2016-$ 2017), the European private equity market grew by $14 \%$ over the same period (Bain \& Company Inc, 2018).
} 
orient cash flows towards positive Net Present Value (NPV) projects that service the debt burden (rather than empire-building and other agency costs), (2) concentrated ownership to avoid free riding on monitoring (which is typical of diffused ownership structures), and (3) management equity stakes to incentivise managers to act as owners. These elements can still be reconciled with current private equity deals because sponsors are the majority or sole owners. They typically use leverage headed to the target to fund the takeover and a management equity stake as an additional monitoring tool. However, other proponents, such as capital market representatives, media, and several scholars, have started to advocate the cruciality of corporate governance mechanisms alongside financial incentives (e.g., Millson \& Ward, 2005).

Since the second wave of private equity investment that ended with the 2008 subprime crisis, operational engineering and active ownership have emerged as distinctive sponsor skills due to increasing competition among sponsors (Cumming et al., 2007; Hoskisson et al., 2013; Siegel et al., 2011). Opportunities were no longer associated with incentive realignment (mechanisms framed by agency theory) alone but with entrepreneurial levers that led sponsors to orient their efforts toward targets' human resources, such as by hiring executives with industry expertise (Cressy et al., 2007; Cumming et al., 2007; Meuleman et al., 2014; Siegel et al., 2011) and other governance mechanisms (Bruining et al., 2013; Klein et al., 2013; Meuleman et al., 2009; Wright et al., 2000, 2009a). According to resource-based theories, the value of an internal resource is associated with the degree to which it enables the company to improve its efficiency and effectiveness through optimal exploitation of internal resources, including human capital (Leiblein, 2011; Meuleman et al., 2014). Resource-based theory (Barney, 1991) argues that value-adding, scarcity, imitability and substitutability are the drivers of a resource's value. Human resources like corporate governance members are hard to buy, imitate and substitute; moreover, they add unique value due to causal ambiguity and tacitness (Leiblein, 2011; Meuleman et al., 2014; Nyberg et al., 2014). In addition, strategic factor market literature associates two main mechanisms with value-adding: the ability to pool uniquely complementary human resources and the highly valuable information in selecting these resources. As highly-specialised players in a competitive market, sponsors are connected and skilled enough to access the human resources needed to replace managers and take board seats.

In this study, private equity is viewed through the lenses of agency theory and resource-based theories for three reasons: firstly, agency theory is useful for framing private equity, as noted. Secondly, the development of the private equity industry over the last decade highlighted the cruciality of internal (human) resources. Thirdly, the focus of this study is corporate governance mechanisms, which are used to operationalise resource-based theories (as is clear in the methodology, agency theory is operationalised by two variables for the auditing and remuneration functions). The most closely related study to this paper is Meuleman et al. (2014)'s work; however, they used the resource-based view in more general terms to capture the activity of sponsors in transferring skills in entrepreneurial buyouts, as opposed to providing the foundation for an empirical analysis focused on specific corporate governance mechanisms affecting private equity deals until the exit. Compared to Meuleman et al. (2014), this study also goes into more detail regarding both the 
corporate governance mechanisms investigated (they only consider the presence of insiders on the board and the directors' experience) and the definition of default (multinomial by the Z-score rather than binomial). Finally, this study employs more recent data and uses a European rather than a UK-based sample. In summary, we aim to contribute to the literature on corporate governance implications of private equity ownership by operationalising internal (human) resources engaged in a private equity deal.

\subsection{Risk of financial distress under private equity ownership}

Sponsors' heterogeneity by type (management versus institution-led); vendor source (primary versus secondary buyout, initial public offering or trade sale); sponsors' experience, reputation, and skills, industry or stage specialisation; deal type; and targets' characteristics are determinants of targets' risk of financial distress (Harford \& Kolasinski, 2013; Hotchkiss et al., 2014; Meuleman et al., 2014; Tykvová \& Borell, 2012). However, though sponsors' corporate governance intervention in their targets is well-known, and despite resource-based theories highlighting the cruciality of internal (human) resources, to our knowledge there is only one study empirically investigating the effect of human resources' interplay with a target's risk of financial distress; the risk of financial distress is relevant because targets are highly leveraged, and leverage figures in agency theory. Meuleman et al. (2014) found a positive effect of board experience and board proximity on the target's risk, but corporate governance was not the focus of their study. Because information on proximity was not available for this study, board industry expertise was used instead of a more general measure of experience. This paper attempts to fill the gap regarding corporate governance by primarily focusing on the effect of corporate governance mechanisms on a target's risk of financial distress (Gong \& Wu, 2011; Meuleman et al., 2014; Wright et al., 2009a).

The choice of the distress risk measure is influenced by the research design. While single-country studies allow for a careful measurement of risk, such as by operationalising national bankruptcy regimes (Wilson \& Wright, 2013), multi-country studies are more generalisable but require less country-specific measures, even if some analyses are more reliable, like Moody's framework (Hotchkiss et al., 2014). ${ }^{2}$ Since this study employed a European sample, the risk of financial distress was proxied with Altman's Z-Score (Altman, 1983; Tykvová \& Borell, 2012), which allowed a multicountry analysis and provided a more granular measurement compared to binary approaches (Harford \& Kolasinski, 2013; Hotchkiss et al., 2014; Meuleman et al., 2014). Existing literature includes cases of single country-based samples, especially in the UK and US (Harford \& Kolasinski, 2013; Meuleman et al., 2014; Wilson \& Wright, 2013) but also in continental Europe, especially France (Boucly et al., 2009, 2011; Desbrières \& Schatt, 2002); and cases of European (Tykvová \& Borell, 2012) and worldwide samples (Hotchkiss et al., 2014).

\footnotetext{
2 Default occurs in the case of a missed interest or principal payment, a filing of a court-led bankruptcy, or the execution of an out-of-court "distressed exchange".
} 
Studies reviewed in this section concluded that private equity ownership reduces (or minimally increases) the risk of financial distress compared to non-acquired control firms. In addition, they emphasised sponsors' distinctive skills.

\subsection{Corporate governance under private equity ownership}

There is widespread agreement about the relationship among ownership and governance. In the case of diffused ownership, shareholders perceive weak incentives to monitor management or are inclined to engage in free-riding due to the disparity between the (fixed) cost of monitoring and the low potential benefits of improved governance. Their equity upside would be limited, and their voting power could become irrelevant. According to agency theory, the interests of ownership and management can be aligned by temporarily giving up the better risk allocation and lower cost of equity benefits of diffused ownership, such as by relying on concentrated ownership (e.g., private equity ownership), leverage and management equity stakes (Achleitner et al., 2013; Cumming et al., 2007; Fama \& Jensen, 1983; Jensen \& Meckling, 1976; Wright et al., 2009a).

The propensity for monitoring is reinforced by the functioning of the private equity market. Because this market is opaque and competitive, sponsors sustain their reputation by achieving consistently strong performances at the fund level (Kaplan \& Sensoy, 2014; Korteweg and Sorensen 2017). In addition, competition induces sponsors to be increasingly specialised and skilled to reach performance goals (Acharya et al., 2013; Cressy et al., 2007; Hotchkiss et al., 2014; Meuleman et al., 2014; Wright et al., 2009a), ${ }^{3}$ and the growing trend of unused funds available to sponsors raises targets' valuations and challenges these goals (Bain \& Company Inc, 2018; Ernst \& Young, 2018; Preqin, 2018). Another impulse to targets' monitoring comes from sponsors' limited economic life (Cumming et al., 2007). ${ }^{4}$

Therefore, despite managers receiving external monitoring, targets' boards still play a crucial role for internal monitoring because sponsors are further motivated by the functioning of the private equity market. Accordingly, sponsors typically intervene in the target's corporate governance through actions like taking board seats (Cornelli \& Karakaş, 2008; Millson \& Ward, 2005; Nikoskelainen \& Wright, 2007). As anticipated, board and other corporate governance members are pivotal internal resources, and their unique combination can add value (Barney, 1991; Leiblein, 2011; Nyberg et al., 2014). Still, there is a gap in private equity literature regarding the joint effect of various corporate governance mechanisms ${ }^{5}$ on a target's risk of financial distress (Gong \& Wu, 2011; Meuleman et al., 2014; Wright et al., 2009a), where risk is relevant because targets are leveraged. Beyond

\footnotetext{
3 An important issue is whether this value creation comes from entrepreneurship, innovation and efficiency or is at the expenses of other stakeholders i.e. value creation versus value capture (Cumming et al., 2007; Wright et al., 2009a, b).

4 Up to 10 years.

5 Board size, directors with industry expertise, directors busyness, duality, monitoring and remuneration sub-boards, management.
} 
the study of Meuleman et al. (2014), other studies have focused on management practices introduced by sponsors (e.g. Bloom et al., 2015) but overlook boards. Since sponsors are skilled and motivated, looking at targets' boards should provide novel insights into what makes a corporate governance setting more effective even outside private equity and whether these features are associated with lower risk of financial distress compared to non-acquired companies.

Studies reviewed in this section concluded that although sponsors are heterogeneous and resource combinations are unique, sponsors exploit their own skills to introduce corporate governance mechanisms that reduce agency costs, thereby enhancing the target's value because agency theory maintains that board internal monitoring complements external monitoring (Cumming et al., 2007; Wright et al., 2009a, b).

\subsection{Hypotheses development}

Since there are no studies explicitly investigating the effect of corporate governance mechanisms on targets' risk of financial distress, hypotheses are developed in this section, where studies are selected based on their pertinence to corporate governance mechanisms in the private equity setting.

Boards are often oversized and tend to shrink when owners want to improve performance and reduce risk (Coles et al., 2008; Cornelli \& Karakaş, 2008; Terjesen et al., 2016), especially in small and medium-sized companies (Di Pietra et al., 2008). With diffused ownership, owners' potential free-riding on monitoring could complicate implementing strategies involving downsizing boards. Furthermore, in the case of less skilled owners, problems and solutions are less likely to be identified and implemented. As sponsors are skilled majority owners who seek profits effectively and efficiently, they may prefer smaller boards (Cornelli \& Karakaş, 2008; Cumming et al., 2007; Gong \& Wu, 2011; Millson \& Ward, 2005), which leads to the following hypothesis.

Hypothesis 1: Reducing board size mitigates the target's risk of financial distress more than in the case of non-acquired companies.

The presence of company representatives and industry experts, in contrast to average private individuals, may provide benefits in terms of knowledge of product market relationships, alleviation of financial constraints, board monitoring (Allen \& Phillips, 2000) and industry expertise (Aldatmaz \& Brown, 2019; Cressy et al., 2007; Cumming et al., 2007; Meuleman et al., 2014). However, frictions leading to greater risk of financial distress could arise among industry experts due to conflicts of interests in indirectly revealing competitors' information, the willingness to receive information from the target as a competitor rather than contributing to its value, or personal conflicts. We argue that sponsors are motivated and skilled owners who commit to resolving conflicts to benefit the target and their investment, which leads to the following hypothesis. 
Hypothesis 2: A higher number of industry experts mitigates the target's risk of financial distress more than in the case of non-acquired companies.

Directors may have multiple roles within a company, especially in larger companies (there is a correlation of .4 among directors' business and size measured by total assets). Although juggling multiple roles may result in lower coordination costs and more efficient economies of scope, busy directors could be less effective and efficient in achieving their tasks (Di Pietra et al., 2008), and the related concentration of decision-making could ultimately be detrimental for the company (Cornelli \& Karakaş, 2008; Millson \& Ward, 2005; Wright et al., 2009b). We argue that sponsors are motivated and skilled owners who also have distinctive experience in allocating tasks among their fund managers, which leads to the following hypothesis.

Hypothesis 3: A higher number of busy board directors mitigates the target's risk of financial distress more than in the case of non-acquired companies.

Duality occurs when the CEO is also the chair of the board of directors. In this study, duality is interpreted as when a manager has a wider mandate than the other managers (if any) and eventually takes the role of chair. Notably, members with dual roles are also classified as busy directors. According to agency theory, duality is associated with greater agency costs due to higher potential for opportunistic behaviour (Jensen, 1993), and empirical evidence tends to confirm this notion (Carter et al., 2003; Di Pietra et al., 2008; Duchin et al., 2010; Terjesen et al., 2016). However, there are theories and evidence that consider duality a positive phenomenon because it renders decision-making more efficient (Davis et al., 1997; Finkelstein \& Mooney, 2003). Sometimes, sponsors use duality as a governance mechanism like other private transactions (Cumming et al., 2007). Agency theory remains a prominent approach to framing private equity. In addition, multiple roles could impair effectiveness due to an excessive number of tasks, especially within private equity deals where there is firm restructuring. While sponsors may prefer identifying a reference manager to carry out execution more efficiently, they may also view duality as a threat to their monitoring because the $\mathrm{CEO} /$ chairman would be a powerful individual in corporate governance. Thus, duality could lead to conflicts between the sponsor and the $\mathrm{CEO} /$ chairman, which leads to the following hypothesis.

Hypothesis 4: Duality increases the target's risk of financial distress more than in the case of non-acquired companies.

Internal auditing and remuneration are typical sub-boards in which sponsors intervene to monitor targets' internal processes and optimise compensation structures for incentivisation (Cumming et al., 2007; Millson \& Ward, 2005), equity stakes (Gong \& Wu, 2011; Wright et al., 2009a), balance among executive and 
non-executive directors, ${ }^{6}$ and other governance mechanisms (Cumming et al., 2007; Millson \& Ward, 2005; Wright et al., 2009a). More resources within these subboards should improve their effectiveness, though inefficiencies may arise at some point, leading to the following hypothesis.

Hypothesis 5: A higher number of directors in the internal auditing and remuneration sub-boards mitigates the target's risk of financial distress more than in the case of non-acquired companies.

According to Hypothesis 4, we expect that a general manager with a wide mandate is not preferable to sponsors, which may be more inclined to allocate execution among several middle-level, more focused managers. This behaviour appears to coincide with expectations about directors' busyness. While the board's decisionmaking could improve efficiency through fewer heads, material and operational execution may improve with specialisation of managers. Hence, we propose the following final hypothesis.

Hypothesis 6: A higher number of managers is preferable to a leading general manager to mitigate the target's risk of financial distress more than in the case of nonacquired companies.

\section{Methodology and sample}

A fixed effects model was not appropriate given sample size limitations due to scarce corporate governance data availability (the data provider Bureau Van Dijk started collecting corporate governance variables in the 2013 fiscal year), the wellknown opacity of privately held companies (Acharya et al., 2013; Cumming et al., 2007; Wilson \& Wright, 2013), and the limited variability of board variables. Thus, a pooled Ordinary Least Squares (hereinafter, OLS) with robust standard errors and time and country dummies was used, where Altman's Z-Score (Altman, 1983) was the continuous response variable to proxy the risk of financial distress (Tykvová \& Borell, 2012) in a more granular way compared to the binomial approaches used in previous studies (Harford \& Kolasinski, 2013; Hotchkiss et al., 2014; Meuleman et al., 2014). Altman's Z-Score is suitable for multi-country samples and comes from a revision of the original Z-Score ${ }^{7}$ to minimise its sensitivity to potential industry effects, such as sales or asset turnover (Altman et al., 2014). The greater the amount of the Z, the lower the risk. Moreover, this study focuses on the post-subprime crisis period in which private equity experienced a bubble (Nikoskelainen \& Wright, 2007; Tykvová \& Borell, 2012). Independent variables included board size and the

\footnotetext{
${ }^{6}$ The variables consisting in equity stakes and the headcount of executive directors are not significant.

7 Altman's Z-Score $=0.717 * \mathrm{X} 1+0.847 * \mathrm{X} 2+3.107 * \mathrm{X} 3+0.420 * \mathrm{X} 4+0.998 * \mathrm{X} 5$ where: X1 = (current assets - current liabilities)/total assets; X2 = cash/total assets; X3 = EBITDA/total assets; X4 = equity/(current liabilities + non-current liabilities); X5 = sales/total assets.
} 
decision-making process; company-type board members and the cruciality of industry expertise; directors' busyness and their effectiveness in managing multiple roles; duality and the way in which power is allocated; and the auditing and remuneration committees and the monitoring and incentivisation functions according to agency theory, or by management equity stakes. Overall, we argue that these aspects of corporate governance are relevant as internal resources framed by resource-based theories, wherein sponsors directly intervene in their targets. In contrast, private equity deals can be generally framed by an agency perspective where leverage, majority ownership, and management equity stakes are typical tools exploited by sponsors.

Since agency theory maintains that the private equity environment is unique due to its ownership and governance features, conclusions about whether sponsors distinctively exploit corporate governance mechanisms can be drawn by comparing targets with non-acquired companies. However, these companies should be similar to targets based on sponsors' screening criteria. Accordingly, propensity score matching was performed based on a target's size in the year before the purchase as well as industry and country.

Despite samples used in the literature are mostly US or UK-based (Achleitner et al., 2010; Cumming et al., 2007; Nikoskelainen \& Wright, 2007; Wright et al., 2009a), a European sample was studied. Privately-held European companies have relatively stringent disclosure requirements, which is notable because these companies tend to be opaque (especially in terms of corporate governance information) and are typically targeted by sponsors (Acharya et al., 2013; Cornelli \& Karakaş, 2008; Cumming et al., 2007; Tykvová \& Borell, 2012; Wilson \& Wright, 2013). Samples were selected from the 2013-2016 period and were drawn by combining Amadeus and Zephyr data from Bureau Van Dijk. Amadeus contains accounting and governance information on European companies and identifies those involved in several deal types, including private equity. Zephyr contains worldwide deals' specifics, including private equity transactions. Since 'leveraged buyout' is not included as a deal type, highly leveraged targets were selected. More specifically, targets and controls $^{8}$ have a debt-to-equity ratio ranging from 1.1 to 16.4 (mean: 3.8; median: 2.7) and 1.2 to 9.5 (mean: 2.6; median: 2.2), respectively, at the 1 st and 99th percentiles. The two groups are balanced until the 50th percentile and then start to diverge (meaning targets are more leveraged). According to available governance information and missing data, the initial sample was of 133 targets and 174 nonacquired companies; after the propensity score matching, there were 310 firm-year observations in which companies had private equity ownership for targets and 86 for controls.

\subsection{Propensity score matching procedure}

Sponsors may acquire distressed companies to minimise purchase prices and unlock greater potential, and companies may rely on private equity to raise funds

\footnotetext{
8 Non-acquired companies.
} 
and implement deep reorganisation through ownership change. Sponsors initially examine potential targets by age, size, industry and country (Cressy et al., 2007; Harford \& Kolasinski, 2013; Scellato \& Ughetto, 2013; Tykvová \& Borell, 2012; Wilson \& Wright, 2013). Therefore, a matching method based on these characteristics is needed to address self-selection and mitigate endogeneity (Hotchkiss et al., 2014; Scellato \& Ughetto, 2013; Tykvová \& Borell, 2012). In the absence of reliable instruments and exogenous shocks, propensity score matching is performed. This approach is preferable to more basic matching procedures because its algorithm considers the response variable used in the subsequent analysis. For this reason, it is often used in private equity literature (Hotchkiss et al., 2014; Scellato \& Ughetto, 2013; Tykvová \& Borell, 2012). However, propensity score matching is limited by the unconfoundedness assumption, which assumes that the treatment sample can be explained only by observable characteristics; however, sponsors conduct due diligence based on soft information. On the one hand, this information is nearly impossible to obtain. On the other hand, this limitation leaves some endogeneity (though the results of this study are confirmed by the literature), whereas self-selection is substantially addressed (Nikoskelainen \& Wright, 2007). Moreover, the two samples are different in size due to size limitations in the initial sample, which led to comparing non-acquired companies with a greater number of targets. Sample size limitations also prevented the inclusion of profitability in the matching because profitability did not ensure balance. Nonetheless, targets were initially screened by size, industry and country, and profitability was included as a control variable in the subsequent analysis.

The procedure used size, industry and country as covariates. Size is well-established as a control variable to identify control samples (Nikoskelainen \& Wright, 2007) and is positively related to company age, which controls for sponsors' stage specialisation (Davis et al., 2014; Nordström, 2015; Tykvová \& Borell, 2012). ${ }^{9}$ Sponsors are also specialised by industry (Cressy et al., 2007). These parameters ${ }^{10}$ are included in the first stage logistic regression, where the response is a dummy that takes one when there is at least one sponsor in the ownership structure in the year in order to derive the odds of receiving private equity (i.e. the treatment). The latter are then used in the second stage nearest neighbour matching with replacement ${ }^{11}$ (Rosenbaum \& Rubin, 1983) to remove 15 observations out of 411, that will drop to 396 (treated: 310; controls: 86) in the empirical analysis due to missing data. While the empirical analysis was based on the 2013-2016 sample, ${ }^{12}$ the first stage shown in Table 1 was performed on the whole sample (2008-2016) to provide a better picture of the likelihood of receiving the treatment sample and improving the matching.

\footnotetext{
${ }^{9}$ Firm age is not included because targets and controls are balanced: targets are slightly younger until the 50th centile and slightly older thereafter. The $90 \%$ of the two samples have firm age above 10 years.

${ }^{10}$ Free cash flows i.e. agency costs (Gong \& Wu, 2011), are not significant in the logit.

11 To address sample size limitations, the command psmatch2 in Stata 14 allows to include the option with replacement in the propensity score matching: this option implies the potential to use a control firm against more than one treated firm.

12 Amadeus collects governance data since 2013.
} 
Table 1 First stage of the propensity score matching
Table 2 Propensity Scores' test of balance

\begin{tabular}{ll}
\hline & $\begin{array}{l}\text { Dependent variable: year in which the } \\
\text { sponsor are in the target's ownership } \\
\text { structure }\end{array}$ \\
\hline Size ${ }_{(\mathrm{t}-1)}$ & $\begin{array}{l}.1663024 * * * \\
(.0477685)\end{array}$ \\
Industry (non-manufac- & -.0273628 \\
turing) & $(.1748993)$ \\
& -.9807845 \\
Constant & $(.5732949)$ \\
& 840
\end{tabular}

This table shows the results of the logit used to derive individual propensity scores for identifying controls. Size is the total assets are of the year preceding private equity ownership and are linearized by natural logarithm; Industry proxies for industry i.e. manufacturing (1) versus non-manufacturing (0) because the Z"-Score i.e. dependent variable of the empirical analysis-is calibrated on this definition of industry; country is not tabulated

${ }^{*} \mathrm{p}<0.05, * * \mathrm{p}<0.01, * * * \mathrm{p}<0.001$

\begin{tabular}{llllll}
\hline Variable & \multicolumn{2}{l}{ Mean } & & \multirow{2}{*}{$\%$ bias } & \multicolumn{2}{l}{ T-test } & \\
\cline { 2 - 3 } & Targets & Controls & & T-test & $\mathrm{p}>$ |t| \\
\hline Size & 10.938 & 10.902 & 2.1 & .29 & .775 \\
Industry & .65300 & .65615 & -.7 & .08 & .934 \\
\hline
\end{tabular}

This table contains the t-tests of the covariates after removing the 15 observations. We consider the variable as unbalanced when p-value is below .05. Country is not tabulated

Table 3 Size descriptive statistics

\begin{tabular}{lllllllll}
\hline Groups & $\mathrm{N}$ & Mean & $\mathrm{se}(\mathrm{mean})$ & $\mathrm{sd}$ & Variance & Range & Skewness & Kurtosis \\
\hline Controls & 86 & 10.95389 & .1852864 & 1.718276 & 2.952471 & 7.097291 & .5955507 & 2.962769 \\
Targets & 310 & 10.97903 & .1021333 & 1.798243 & 3.233676 & 7.764752 & .3370043 & 2.448119 \\
\hline & $\mathrm{p} 1$ & $\mathrm{p} 5$ & $\mathrm{p} 10$ & $\mathrm{p} 25$ & $\mathrm{p} 50$ & $\mathrm{p} 75$ & $\mathrm{p} 90$ & $\mathrm{p} 99$ \\
\hline Controls & 7.471716 & 8.441808 & 9.218092 & 9.782575 & 10.72535 & 11.90046 & 14.34401 & 14.56901 \\
Targets & 7.412764 & 8.073272 & 9.044274 & 9.760155 & 10.69120 & 12.13731 & 13.80255 & 14.76981 \\
\hline
\end{tabular}

This table includes descriptive statistics of size i.e. standardized total assets-Panel A contains mean, standard error of the measurement of the mean, standard deviation of the mean within its distribution, variance, range among $\min (\mathrm{U}:-2.538316$; $\mathrm{T}:-2.585692)$ and $\max (\mathrm{U}: .8808103$; T: 1.154984), skewness and kurtosis, and several points $(1,5,10,25,50,75,90,99)$ of the distribution for treated i.e. targets - and untreated i.e. controls. Panel B multiplies by - 100 and rounds these values to obtain more intuitively comparable values 
Table 4 Distribution of the matched sample by year, country, and industry

\begin{tabular}{llllll}
\hline Year & Treated & Untreated & Country & Treated & Untreated \\
\hline 2013 & 72 & 29 & Belgium & 26 & 5 \\
2014 & 77 & 24 & Finland & 22 & 2 \\
2015 & 80 & 20 & France & 89 & 10 \\
2016 & 81 & 13 & Germany & 2 & 6 \\
Total & 310 & 86 & Norway & 58 & 8 \\
& & & Portugal & 5 & 7 \\
Industry & Treated & Untreated & Spain & 45 & 15 \\
Non-manufacturing & 205 & 53 & Sweden & 22 & 10 \\
Manufacturing & 105 & 33 & UK & 41 & 23 \\
Total & 310 & 86 & Total & 310 & 86 \\
\hline
\end{tabular}

Thus, by comparing targets with companies that are likely to receive private equity, the effect of governance mechanisms should be more reliably associated with private equity ownership.

Results show that sponsors significantly prefer larger companies (the untabulated results of Size divided into quintiles show that sponsors prefer middle-sized companies, which are mostly privately-held companies) because size is positively related to deal returns (Nikoskelainen \& Wright, 2007). Industry sector is not relevant, which may be because sponsors prioritise stage, size, the potential of reducing agency costs and resolving governance frictions, or their networks allow for lower restrictions on industry. The balance test in Table 2 indicates that samples are balanced.

To obtain a better picture of size, a more granular comparison was performed. Table 3 shows that size is balanced unless companies belong to the 75 th percentile, which have slightly different values. ${ }^{13}$

Therefore, we can conclude that size is balanced among the samples.

Table 4 presents a description of the matched samples by country, industry, and year, while the following section is devoted to describing the focus variables of this study.

\subsection{Board descriptive statistics}

Boards were subject to univariate analysis by size and composition to obtain preliminary evidence of the effect of private equity ownership on corporate governance,

\footnotetext{
${ }^{13}$ Leverage as measured by (Current Liabilities + Non-Current Liabilities)/Equity is substantially balanced too, with targets being slightly more leveraged (median 2.2 versus 2.7 for targets and control, respectively); debt coverage defined as (Current Liabilities + Non-Current Liabilities)/Cash is optimally balanced among the two groups. These variables proxy agency costs: leverage captures incentives from leverage, whereas cash flows (herein debt coverage indicates the "years needed to service the debt at current cash flow generation rate") capture the potential of opportunistic management's behavior (Gong \& Wu, 2011; Nikoskelainen \& Wright, 2007).
} 
Table 5 Matched sample variables' descriptive statistics

\begin{tabular}{|c|c|c|c|c|c|}
\hline & \multicolumn{2}{|l|}{ Mean } & \multicolumn{2}{|l|}{ Std. Err. } & \multirow{2}{*}{$\begin{array}{l}\text { Diff (mean) } \\
\text { Controls-targets }\end{array}$} \\
\hline & Targets & Controls & Targets & Controls & \\
\hline Altman's Z-Score & 2.193 & 2.278 & .101 & .199 & .085 \\
\hline Board size & 6.674 & 7.081 & .351 & .694 & .407 \\
\hline Board duality & .500 & .407 & .028 & .053 & -.093 \\
\hline N. of busy board directors & .990 & 1.105 & .086 & .194 & .114 \\
\hline N. of industry experts in the board & .060 & .034 & .008 & .011 & $-.027 *$ \\
\hline $\begin{array}{l}\text { N. of board directors serving the audit com- } \\
\text { mittee }\end{array}$ & .106 & .140 & .034 & .070 & .033 \\
\hline $\begin{array}{l}\text { N. of board directors in the remuneration com- } \\
\text { mittee }\end{array}$ & .116 & .105 & .040 & .060 & -.011 \\
\hline N. of managers & 3.453 & 2.719 & .529 & .271 & .734 \\
\hline General manager dummy & .316 & .233 & .026 & .046 & -.084 \\
\hline
\end{tabular}

Variables are described in detail in the Table 8 in the Appendix section

with some attention devoted to management. The subsequent section concerns the effect of these mechanisms on targets' risk of financial distress compared to controls.

Table 5 gives the results of t-tests conducted on all the focus variables employed in the empirical analysis in relation to the subsamples of treated (targets) and controls (non-acquired companies balanced by size, country, and industry).

\subsubsection{Board size}

Sponsors tend to reduce board size by 0.4 heads during their ownership, but since the t-statistic is lower than one, board size could be largely the same among the two groups. Additionally, untabulated frequency distributions show that during private equity ownership, 50\% (80\%) of boards are between 3 and 5 (2-8) members, whereas outside private equity ownership, 53\% (80\%) of boards are between 3 and 6 (2-10) members. Moreover, management buyout targets have smaller boards during private equity ownership ( 8 as opposed to 6 heads in 80\% of cases) and larger reductions (from 6.9 to 4.9 ) in board size after private equity ownership compared to other private equity (Cornelli $\&$ Karakaş, 2008). These results suggest that sponsors use board size as a governance mechanism, while outside private equity ownership companies are more heterogeneous. These results are in line with the literature that evidences the negative performance associated with overly large boards that necessitate reductions in board size during private equity ownership when sponsors are skilled (Cornelli \& Karakaş, 2008; Cumming et al., 2007; Gong \& Wu, 2011; Millson \& Ward, 2005). However, the lower board size outside private equity ownership could also reflect sponsors leaving boards at exit rather than a structural difference. As an additional test, we checked whether board size was larger in the case of club deals or deals where the acquiror is a syndicate of two or more private equity sponsors-each sponsor seeks a board seat as a form of monitoring over both the company and the syndicate (Cornelli \& Karakaş, 2008). Untabulated $\mathrm{t}$-tests indeed indicate that targets of club deals have larger boards ( 8.2 versus 
Table 6 Altman Z"-Score before, during, and after private equity ownership

\begin{tabular}{lllllll}
\hline-3 & -2 & -1 & 0 & +1 & +2 & +3 \\
.0846824 & .1187927 & .1611612 & 1.716750 & .0344679 & .0286461 & .015937 \\
\hline
\end{tabular}

6.7 heads). Additionally, untabulated OLS regressions of private equity ownership and number of sponsors against board size indicates that (syndicated) private equity ownership reduces (increases) board size by 2.5 (1.8) heads. Moreover, there is a positive correlation (whole sample: $13.2 \%$; targets: 13.8\%) between board size and risk of financial distress, indicating that troubled companies are associated with larger boards (Cornelli \& Karakaş, 2008).

With respect to risk, Table 5 suggests that private equity ownership is associated with slightly increased risk of financial distress (Tykvová \& Borell, 2012), though this result is not significant due to the low t-statistic. This result could also be due to the slightly greater leverage of targets, which lowers the Z-Score. As observed in Table 6 below, risk is lower during the deal compared to the three years preceding private equity ownership, although targets were already improving their risk profile, and it steadily worsened in the three years after, suggesting that private equity ownership improves governance (Hotchkiss et al., 2014; Wilson \& Wright, 2013).

\subsubsection{Board duality}

Duality is more likely during private equity ownership as well as the number of outside directors in untabulated t-tests (Cumming et al., 2007; Millson \& Ward, 2005; Wright et al., 2009a). According to other untabulated t-tests, sponsors also reduce the number of members holding an equity stake (and likely increase the number of stakes). The increase of outside directors indicates that the market for corporate control, or equity stakes, is complementary and not alternative to outside directors' monitoring. Moreover, the increased duality may suggest that sponsors want to concentrate management execution (Millson \& Ward, 2005; Wright et al., 2009a). Untabulated OLS regressions confirmed that private equity ownership increases duality and the number of outside directors, while syndication slightly reduces duality. Multiple sponsors may not prefer delegation to one single individual (Cornelli \& Karakaş, 2008). However, other untabulated OLS regressions indicated that in the presence of duality, the number of executive directors increases by 0.9 heads, whereas in the case of private equity ownership, the effect is less clear. Accordingly, $80 \%$ of targets' boards have zero or one executive director, while controls are more homogeneous (Cumming et al., 2007). However, sponsors increase the percentage of managers by 1.8 heads, which suggests that sponsors prefer to centralise decision-making within the board and to delegate execution to a larger management team.

\subsubsection{Number of busy board directors}

There is evidence that private equity funds investing in fewer projects achieve better returns, implying that less busy managers add more value (Wright et al., 2009b). 
Therefore, sponsors are able to balance economies of scope with specialisation. As shown in Table 5, private equity ownership reduces the number of busy directors from 1.1 to 1.0 members, and targets exhibit much lower variability, although the difference is not significant due to the low t-statistic. Nonetheless, it should be noted that an increase in duality also consists of an increase in members having more than one role and thus increased busyness. As such, sponsors cannot consider busy managers to be less effective.

\subsubsection{Number of industry experts in the board}

In terms of the type of expertise that sponsors prefer in their targets, the sample confirms the literature regarding sponsors' propensity to rely on industry experts (Cressy et al., 2007; Cumming et al., 2007; Meuleman et al., 2014), in this case proxied by directors who are company representatives rather than private individuals. Table 5 suggests that sponsors increase the percentage of industry experts from 3.4 to $6 \%$ (Cumming et al., 2007; Millson \& Ward, 2005), which is in line with Table 1. Hence, if sponsors do not prioritise industry in selecting targets, they may need industry experts during the holding period.

\subsubsection{Number of directors serving the audit committee; number of directors in the remuneration committee}

Firstly, both groups tend not to hire many of these professionals, but their contribution is relevant in that they apply important dimensions of monitoring (Cumming et al., 2007; Di Pietra et al., 2008; Millson \& Ward., 2005; Wright et al., 2009a). Secondly, targets have a lower proportion of auditors but not remuneration surveyors. Thirdly, the variability is lower for targets, suggesting more defined strategies concerning these members. Thus, sponsors' monitoring may substitute to an extent for that of professionals, or sponsors need to appoint fewer members to provide the necessary monitoring. However, neither result is significant due to the considerably low t-statistic.

Other univariate analyses concern management and indicate that targets have a lower number of managers on average (2.68 against 3.45$)$ but rely on top management or general managers more than controls $(0.32$ versus 0.23$)$; in both cases, targets exhibit lower variability ( 0.26 versus 0.53 for the number of managers; 0.46 versus 0.26 for the general manager). These findings are supported by the literature and indicate that sponsors tend to concentrate a large executive mandate within one or a few managers (Kaplan \& Strömberg, 2009).

These results are in line with previous findings, but differences are not statistically significant unless a threshold exceeding $10 \%$ is adopted. The limited sample depth could hamper the reliability of the results. The lack of significant differences could be due to sponsors better selecting, training, and/or exploiting corporate governance members rather than just changing their numbers. Therefore, to investigate the effect of these variables on the risk of financial distress, they are included in a multivariate setting. If targets exhibit a lower risk associated with corporate governance mechanisms compared to controls, this result signals a positive effect of private 
Table 7 The impact of corporate governance mechanisms on the risk of financial distress

\begin{tabular}{|c|c|c|c|}
\hline & \multicolumn{3}{|c|}{ Altman's Z"-Score } \\
\hline & (1) & (2) & (3) \\
\hline PE & $\begin{array}{l}-.35^{*} \\
(.20)\end{array}$ & $\begin{array}{l}-.34^{*} \\
(.20)\end{array}$ & $\begin{array}{l}-.25 \\
(.19)\end{array}$ \\
\hline Board size & $\begin{array}{l}-.021 \\
(.09)\end{array}$ & & \\
\hline PE*Board size & $\begin{array}{l}-.38^{* * * *} \\
(.13)\end{array}$ & & \\
\hline Perc. of industry experts & $\begin{array}{l}-.17 \\
(.16)\end{array}$ & & \\
\hline PE*Perc. of industry experts & $\begin{array}{l}3.18 * * \\
(1.52)\end{array}$ & & \\
\hline N. of busy directors & $\begin{array}{l}-.40^{* *} \\
(.17)\end{array}$ & & \\
\hline $\mathrm{PE}^{*} \mathrm{~N}$. of busy directors & $\begin{array}{l}.48 * \\
(.25)\end{array}$ & & \\
\hline Board duality & & $\begin{array}{l}.44 * * * \\
(.17)\end{array}$ & \\
\hline PE*Board duality & & $\begin{array}{l}-.15 \\
(.37)\end{array}$ & \\
\hline N. of directors serving the audit committee & & $\begin{array}{l}-.33 * * * \\
(.10)\end{array}$ & \\
\hline PE*N. of directors serving the audit committee & & $\begin{array}{l}-.14 \\
(.14)\end{array}$ & \\
\hline N. of directors in the remuneration committee & & $\begin{array}{l}.41 * \\
(.21)\end{array}$ & \\
\hline $\mathrm{PE}^{*} \mathrm{~N}$. of directors in the remuneration committee & & $\begin{array}{l}-.47 * * \\
(.22)\end{array}$ & \\
\hline General manager & & & $\begin{array}{l}.49 * * \\
(.19)\end{array}$ \\
\hline PE*General manager & & & $\begin{array}{l}-.36^{* *} \\
(.17)\end{array}$ \\
\hline N. of managers & & & $\begin{array}{l}-.35^{* *} \\
(.14)\end{array}$ \\
\hline PE*N. of managers & & & $\begin{array}{l}.38 * * \\
(.17)\end{array}$ \\
\hline $\mathrm{CASH} / \mathrm{OR}$ & $\begin{array}{l}4.27 * * * \\
(.85)\end{array}$ & $\begin{array}{l}4.27 * * * \\
(.96)\end{array}$ & $\begin{array}{l}3.99 * * * \\
(.85)\end{array}$ \\
\hline $\mathrm{PE} * \mathrm{CASH} / \mathrm{OR}$ & $\begin{array}{l}-3.03 * * * \\
(.90)\end{array}$ & $\begin{array}{l}-3.04 * * * \\
(1.00)\end{array}$ & $\begin{array}{l}-2.79 * * * \\
(.91)\end{array}$ \\
\hline ROE & $\begin{array}{l}1.08 * * * \\
(.27)\end{array}$ & $\begin{array}{l}.94 * * * \\
(.23)\end{array}$ & $\begin{array}{l}.87 * * * \\
(.25)\end{array}$ \\
\hline $\mathrm{PE} * \mathrm{ROE}$ & $-.64 * *$ & $-.46^{*}$ & -0.43 \\
\hline
\end{tabular}


Table 7 (continued)

\begin{tabular}{llll}
\hline \multirow{4}{*}{ Altman's Z"-Score } \\
\cline { 2 - 4 } & $(1)$ & $(2)$ & $(3)$ \\
\hline \multirow{2}{*}{ Constant } & $(.30)$ & $(.28)$ & $(.29)$ \\
& $2.69^{* * *}$ & $2.8^{* * *}$ & $3.06^{* * *}$ \\
Obs & $(.40)$ & $(.35)$ & $(.37)$ \\
$\mathrm{R}^{2}$ & 396 & 396 & 396 \\
Country dummy & .352 & .368 & .333 \\
Year dummy & YES & YES & YES \\
\hline
\end{tabular}

equity ownership. In other words, since boards are similar unless private equity ownership is considered, then private equity can be considered the source of potential differences in their effects on the risk of financial distress.

\section{Results}

This section is devoted to the empirical analysis. Table 7 contains results of three model specifications. The focus variables for corporate governance mechanisms operationalize internal (human) resources as framed within resource-based perspectives. These mechanisms are considered within private equity deals that can be viewed through the lenses of the agency theory. Moreover, agency theory is operationalised by measuring auditing (monitoring) and remuneration functions. Notably, statistical significance and the magnitude of coefficients are largely stable across the three specifications, suggesting greater reliability compared to using a single specification. These results add value by providing a comprehensive view of sponsors' corporate governance intervention, thus complementing the sparse existing evidence on the topic. This gap needs to be filled because corporate governance intervention is a distinctive tool used by sponsors.

\subsection{Board size}

Hypothesis 1 is confirmed by the results. More specifically, while changes in board size have an ambiguous effect on the risk of non-acquired companies, when sponsors reduce board size there is significant improvement in the risk profile of the target. Therefore, sponsors apply this governance mechanism more effectively because they are more skilled in exploiting internal (human) resources and are more motivated to manage the company successfully. Another potential interpretation is that sponsors prefer more concentrated decision-making. The results regarding board size seemingly conflict with Coles et al. (2008), who found that board size positively affects leveraged companies. They considered Tobin's $\mathrm{Q}$ as a dependent variable and argued that leveraged companies need more advising through more directors to reduce the cost of 
borrowing. However, in private equity deals, the advisory function is mainly provided by sponsors as part of their monitoring to allow for board size reduction when necessary. Similarly, Terjesen et al. (2016) found that board size negatively affects Tobin's $\mathrm{Q}$ and Return On Asset (ROA). We argue that increased risk in a leveraged company would be followed by a drop in its value, as proxied by the Q. Furthermore, we argue that leveraged companies can be investigated more effectively by looking at their risk of financial distress rather than their profitability (ROA). Moreover, in addition to profitability as a control variable, the Z-Score also includes ROA in its formula. Di Pietra et al. (2008) similarly found that board size negatively affects profitability. Though they considered a sample of listed Italian companies only, their results support our study in that they found significant results only for small companies. Finally, and more marginally, Cornelli and Karakaş (2008) found that experienced sponsors reduce board size. Since sponsors are also motivated to successfully manage their targets, this confirms that board size reductions are associated with successful strategies within targets, with improvements through reduced risk of financial distress.

\subsection{Number of industry experts in the board}

Hypothesis 2 is confirmed: company representatives strongly contribute to mitigating targets' risk of financial distress, while in the case of the controls the relationship is negative but not statistically significant. Meuleman et al. (2014) argued that experienced board members have more industry expertise; while we support this view, we used company-type board members to provide a more careful proxy of industry expertise within a board. In this regard, Allen and Phillips (2000) concluded that companytype board members provide benefits in terms of increased stock price due to improved product market relationship and general industry expertise. Allen and Phillips' (2000) analysis was devoted to listed companies, but we maintain that the beneficial effect of leveraged privately held targets would manifest through another channel, such as a decrease in the risk of financial distress due to a better use of operating levers (Hoskisson et al., 2013; Siegel et al., 2011). Notably, industry expertise is valuable both in listed and privately held companies like targets. Cressy et al. (2007) determined that targets benefit when sponsors are specialised by industry. Although we did not consider the sponsor's specialisation profile, we argue that sponsors-as skilled and motivated owners-are specialised at least by industry and that company-type board members may complement rather than substitute their specialisation by industry. This claim is supported by Cumming et al.'s (2007) observation that targets outperform industry peers. More marginally, since Aldatmaz and Brown (2019) discovered that sponsors spur industry spillovers after their deals, we argue that results support the view of sponsors being skilled and motivated owners that are specialised at least by industry.

\subsection{Number of busy board directors}

This variable is significant for both groups and confirms Hypothesis 3 that sponsors are more effective in allocating multiple roles across directors, whereas nonacquired companies tend to face a greater risk from busier directors. This evidence 
is coherent with the univariate analysis in which board size and risk shrink during private equity ownership and with the view that sponsors are highly skilled active investors. However, because sponsors usually delegate crucial decision-making and execution to a single executive they appoint or monitor, busy directors of targets could be in charge of simpler tasks, whereas directors of controls may have to make more decisions that exacerbate negative aspects of being busy. These explanations seem not exclusive with one other. Moreover, sponsors may purchase targets whose governance needs corrective actions, including a more careful allocation of tasks among board members. Di Pietra et al. (2008) also found evidence of the beneficial effect of busier directors in small companies; however, they considered operating performance rather than the risk of financial distress as their dependent variable and did not consider leveraged companies or whether improved performance comes at the expense of a greater risk of financial distress. Nevertheless, their results support our study in their significance for smaller companies.

\subsection{Board duality}

The results of the controls align with agency theory, but Hypothesis 4 is not confirmed. While the coefficient for targets is negative and not significant, that of controls is positive and significant. Therefore, while controls are less effective when their directors are busy, when one of the busy directors has a dual role, then the risk is reduced. This finding is consistent with empirical literature. Though Terjesen et al. (2016) related duality to Tobin's Q, this study considered the risk of financial distress as a dependent variable because the focus was on leveraged firms. As with board size, sponsors tend to introduce less duality as experienced and motivated owners. We therefore argue that an increase in Tobin's Q due to less duality would correspond to a lower risk of financial distress in leveraged targets. In addition, sponsors' lower inclination for duality could be due to their preferences regarding governance structures. More specifically, since the correlation between duality and both the number of managers (.06 for targets and .01 for controls) and busy directors (.03 for targets, and .07 for controls) is not negative, duality may be associated with a not greater concentration of execution and decision-making. Therefore, in contrast with the typical view on private equity, sponsors successfully introduce more concentrated decision-making (smaller boards and busier directors), but it is not clear whether they set up more dispersed execution (less duality). More precisely, the relationship between private equity ownership and duality is unclear as there are some cases of targets with no duality as well as cases of those with duality. These results could reflect the cruciality of an efficient strategy formulation coupled with a specialised execution, thus confirming the post-subprime trends in the private equity market (Cumming et al., 2007; Hoskisson et al., 2013; Siegel et al., 2011). Additionally, these results could be the effect of club deals, in which two or more sponsors could view duality as a solution that does not resemble the ownership structure. Duality could reflect sponsors' orientation towards a more concentrated decisionmaking to make corporate restructuring more efficient and to facilitate interactions 
if relevant decision power is allocated to more than one top member of the corporate governance.

\subsection{Number of directors serving the audit committee and N. of directors in the remuneration committee}

Whereas Di Pietra et al. (2008) documented that incentives from monitoring and remuneration plans are beneficial in agency theory, in this study, the coefficients for auditing and remuneration associated with private equity are negative. The coefficient for the audit committee is not significant, while for the control sample are significant. Given that the signs are negative for targets and negative for controls, Hypothesis 5 is not confirmed. However, in this study we considered the auditing and remuneration sub-boards operating through the whole target. Conversely, Di Pietra et al. (2008) referred to the effect of CEO compensation on value added, and they investigated this relationship outside private equity ownership. Thus, the inconsistency between our results could be due to these differences and the uniqueness of the private equity setting. Our results for non-acquired companies coincide with Di Pietra et al.'s (2008) findings. With respect to targets, club deals ${ }^{14}$ could experience conflicts and/or inefficiencies when appointing more than one individual to these sub-boards or when sponsors join or monitor incumbents. Alternatively, and more feasibly, the function deployed by these sub-boards inefficiently duplicates sponsors' monitoring. In this regard, the insignificance of the audit committee could be because, in most cases, monitoring is performed directly by sponsors rather than through sub-boards. However, the relation is not completely clear because there could be cases where the audit committee is undersized ex-ante. In other words, while having more than one sub-boards' members is generally a positive feature, within private equity ownership there could be duplications or conflicts among sponsors and/or among incumbents and new members of sub-boards. Another potential explanation is that these two sub-boards are associated with targets that had more agency costs ex-ante that will be mitigated over the longer term.

\subsection{General manager dummy and number of managers}

In this study, while more concentrated decision-making is associated with targets' risk reductions - that is, busier directors are preferable to more directors with narrower mandates - the results concerning duality and general managers suggest that a less concentrated execution leads to targets' risk reduction. More specifically, a general manager having a wide mandate is positively (negatively) exploited by controls (targets), which have a preference for more (less) concentrated execution and wider (narrower) decision-making. Notably, the correlation among the presence of a general manager and that of duality is negative and less than .2 for both groups. The coefficients' magnitudes are similar, but that of controls includes cases of nearly

14 Those where at least two sponsors jointly purchase a target. 
no effect. Thus, the upside of private equity does not relate only to incentives but also on entrepreneurial levers (Bruining et al., 2013; Klein et al., 2013; Meuleman et al., 2009; Wright et al., 2000). Again, as with other evidence in this study and the literature on management practices introduced by sponsors, an increase in the number of managers (i.e. a more dispersed execution) mitigates targets' risk. Therefore, Hypothesis 6 is confirmed. Sponsors may improve targets' management practices by spurring managers' effectiveness through specialisation and attraction/replacement of human capital. Accordingly, sponsors not only provide finance but also managerial skills to their targets (Bloom et al., 2015). Thus, while busy directors may have a more global picture of the target, when it comes to execution, managers having the chance to devote more time and to apply specialised skills may be more effective than those having a wider mandate. As such, the presence of a CEO, CFO, or president is not significant and mostly with negative sign; the same holds for executive directors, probably because executive duties are assigned preferably to managers rather than directors. However, this variable is not significant in either group. Moreover, since the sample includes privately-held companies, their governance may not include formal roles such as the CEO or the CFO.

\subsection{Cash/operating revenue and return on equity}

These control variables capture the use of liquid funds scaled by operating revenue and the corporate revenues scaled by the amount of equity invested. In particular, the former variable can be interpreted as measures of agency costs (Gong \& Wu, 2011; Meuleman et al., 2014; Wilson \& Wright, 2013) and a control for operating performance. A greater availability of free cash flows increases the potential of their opportunistic use, such as in negative NPV projects or empire-building (Cumming et al., 2007; Wright et al., 2009a). The latter variable can be interpreted as yielding better operating performance associated with a lower risk of financial distress when not produced by negative NPV projects (Hotchkiss et al., 2014; Meuleman et al., 2014; Wilson \& Wright, 2013). Consistent with this view, the coefficients are significant. While the coefficients of targets are negative, those of controls are positive and have a greater magnitude. In addition, ROE has a lower magnitude than CASH/ OR; this suggests that for targets, the lower the liquid funds (i.e. agency costs), the lower the risk. Furthermore, the greater the ROE, the greater the risk of financial distress. Wilson and Wright (2013) and Meuleman et al. (2014) measured the likelihood of bankruptcy and produced negative and significant coefficients in the variables proxying agency costs. Therefore, a higher amount of cash flows lowers the risk of bankruptcy. ${ }^{15}$ Wilson and Wright (2013) and Meuleman et al.'s (2014) results contrast with the results of this study, but they used a binary model that focused on bankruptcy rather than a more granular view of the risk of financial distress. In other words, since bankruptcy is different from financial distress, there may be different mechanisms associated with cash flows in the two scenarios. For example,

15 Gong and $\mathrm{Wu}$ (2011) find a positive coefficient on cash flows, but they do not focus on risk. 
while cash flows may be used opportunistically in a distressed situation according to agency theory, cash flows in companies near bankruptcy could positively affect the liquidation process. For controls, less concentrated decision-making and narrower execution are associated with a better use of free cash flows. The wider execution within targets may exacerbate agency costs of cash flows and free riding because a higher number of managers is harder to monitor. Controls' more concentrated execution mitigates this eventuality. Thus, sponsors may consider wider execution structures (which, per se, tend to mitigate risk) in the case of low amounts of cash flows. However, controls receive more scrutiny from banking-type lenders who are interested in their long-term survival and debt servicing. In contrast, targets' executives are sometimes appointed by sponsors and then removed just after exit to apply their skills in other deals. Hence, some of these managers could be affected by shorttermism. The limited time horizon of deals could also incentivise some sponsors to use their own discretion for sustaining their reputation by successful exits that do not necessarily imply structural value creation and/or risk reduction. Accordingly, the lower significance of coefficient for targets' CASH/OR and ROE than those of controls could be due to some sponsors being more virtuous than others. With respect to ROE, Wilson and Wright (2013), Hotchkiss et al. (2014), and Meuleman et al. (2014) found negative coefficients associated with operating performance. Their findings were not confirmed by this study. Similarly to the case of agency costs, the reason could lie in bankruptcy firms being different from distressed companies. In this study, the reason could be that bankruptcy firms have reduced their equity and/or that returns are associated with divestments aimed at financing the liquidation. These studies use ROA and the return on sales, but assets and sales could also decline following bankruptcy for similar reasons.

\section{Conclusion}

Corporate governance mechanisms are meaningful within the private equity model, despite the lack of significant differences among boards of targets and non-acquired companies in the univariate analysis. However, sponsors use governance mechanisms better than other ownership structures. Notably, compared to the existing literature, the results of this study allow for a more comprehensive view of how sponsors intervene in the corporate governance of their targets. More precisely, the positive effect of private equity ownership is associated with less concentrated (and, presumably, better defined) decision-making as well as wider execution i.e. busier directors in absence of duality or a general manager with a greater number of managers - within smaller boards, in which industry experts provides a valuable contribution. Therefore, sponsors better exploit internal (human) resources as skilled and motivated majority owners. However, the size of sub-boards such as auditing and remuneration committees needs to be addressed carefully. Firstly, the audit committee could lose flexibility when oversized and, in some targets, could suffer from the presence of an additional member, particularly the sponsor's representative (or representatives, in the case of club deals). Secondly, the remuneration committee may have to be revised downwards to improve its contribution to incentivisation and risk 
reduction. This mechanism is positively exploited by controls, the dispersed ownership structure of which may mitigate the risk of sub-boards' oversize with conflicts due to duplication of sponsors' monitoring and club deals. Finally, evidence from cash flows suggests that targets have greater agency costs than controls. Thus, sponsors could consider matching the governance structures they introduce (whose mitigation effect on risk is valuable) to financial structures that imply low amounts of cash flows.

Lenders and shareholders that remained in the company during the private equity ownership ${ }^{16}$ could use this evidence to improve their monitoring. More specifically, shareholders may adjust their expectations about a firm's creditworthiness if its governance setting departs from what sponsors introduced during the deal. Furthermore, lenders can consider applying clauses related to governance aspects, such as more intervention in the firm's strategy and governance if board size increases too much.

Scrutinised targets can develop better expectations about the corporate governance implications of private equity ownership. These implications may be crucial to discouraging some firms from engaging in a deal. In turn, this reduces both sunk costs associated with inconclusive due diligences because the negotiation is interrupted earlier and the larger reputational and financial costs associated with deals that become unsuccessful due to governance rigidities.

Importantly, since sponsors are skilled owners that perceive strong incentives for generating strong performance, these results may provide some insights into what makes corporate governance effective for managers even outside private equity ownership. For example, sponsors can use their power to better contribute to corporategovernance-related decisions.

Moreover, investors can refine their criteria when ranking firms. However, this study is devoted to privately held companies with corporate governance information that may be difficult to access for investors.

These results could also be useful to policymakers who may consider fostering private equity through law, such as by increasing flexibility within ownership changes or setting incentives for foreign institutional investors to promote the sharing of governance and investment best practices. Such legislation could support firms in financial distress, which would be viewed as investment opportunities by private equity sponsors specialised in turnarounds.

Private equity ownership is a unique governance mechanism that is based on a few owners, active monitoring and a strong incentive structure (within the target), and the sponsors' performance-based reputation as well as the limited life of the funds they manage (outside the target or private equity market). Thus, these results should not be generalised outside private equity.

This study has several limitations. The limited sample size reduces the results' reliability and the effectiveness of the propensity score matching. More specifically,

\footnotetext{
16 Since companies are privately-held, new shareholders may not have enough information to observe the corporate governance setting, whereas existing shareholders have company-specific information about governance practices introduced by sponsors and post-exit governance practices.
} 
privately held companies are sponsors' typical targets but are also opaque. As such, large samples including corporate governance information are rare, and governance structures are unique. These elements challenged the identification of control firms and led to suboptimal solutions like comparing a given control firm with more than one target. Moreover, while matching procedures were designed for addressing selection bias, they are less effective against endogeneity. Since exogenous shocks and instruments were not available for this study, and although results align with past literature, their reliability could not reach its potential. Finally, the limited sample size makes it difficult to add variables such as individuals' curricula or sponsors' characteristics.

In conclusion, the underlying limitation of this study-and of corporate governance literature in general-is its limited sample size. Future research could collect larger samples to overcome these limitations and provide a considerable contribution to the literature. Since larger samples increase the degree of freedom, this does not conflict with the addition of more fine-grained variables regarding individuals' personal traits or information from curriculum vitae. From a methodological point of view, more careful consideration of endogeneity would be fundamental to improving the reliability of empirical results. Moreover, further research is needed to understand how sponsors intervene in targets' corporate governance, such as listed versus privately-held companies; how and why sponsors intervene differently in different types of targets; which individual and sponsor characteristics improve or worsen deals' outcomes; the effect of macroeconomic conditions such as policy measures, country characteristics, and culture; and whether targets learn from positive practices that sponsors introduce.

\section{Appendix}

See Table 8 . 


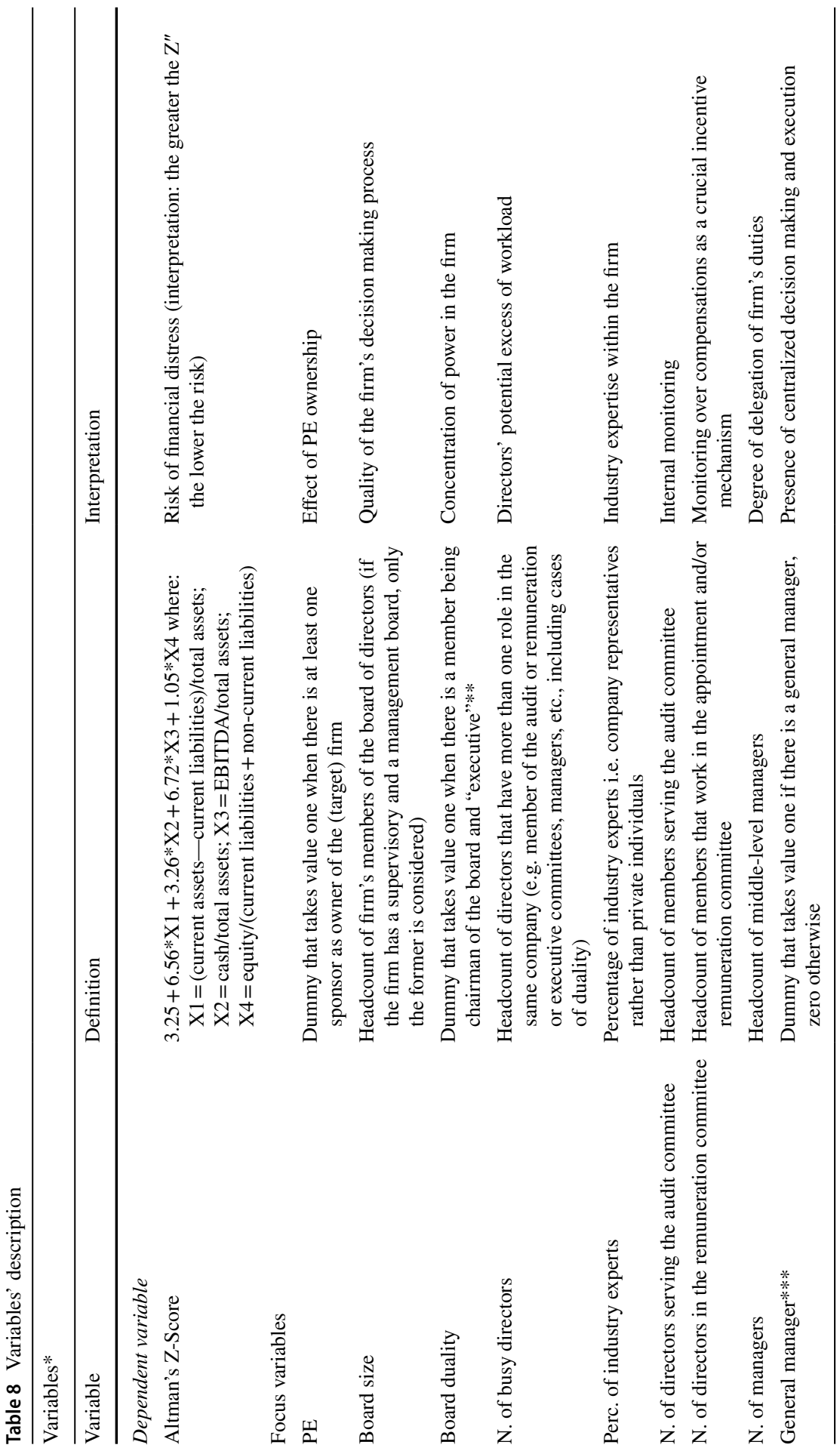




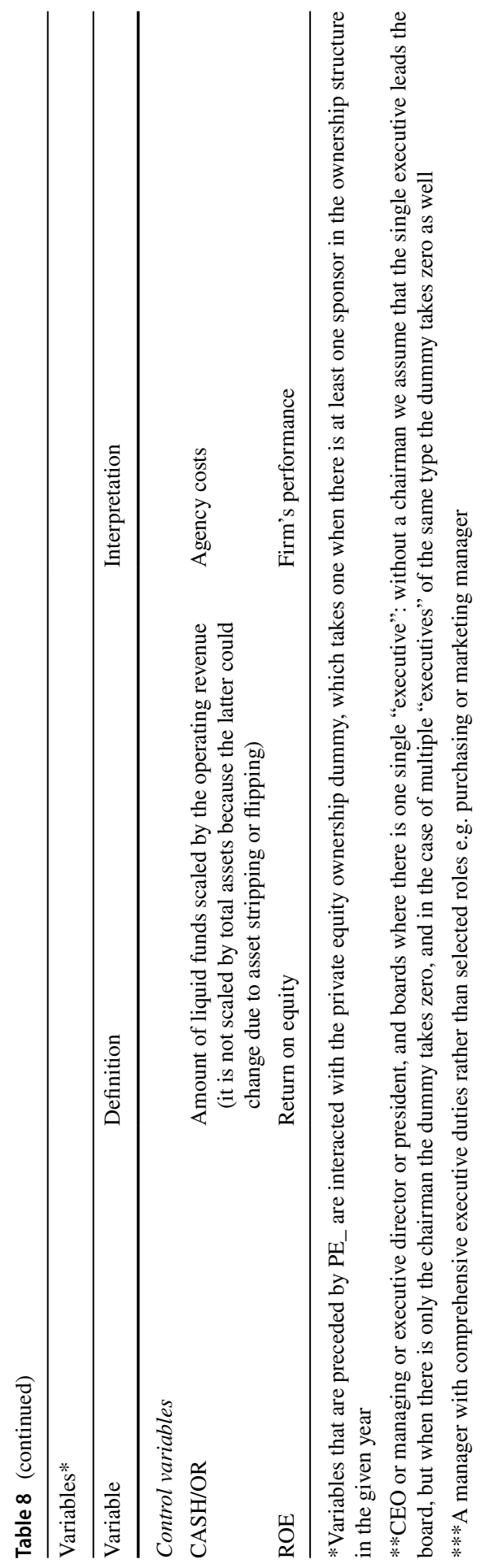


Funding Open access funding provided by Università degli Studi di Roma Tor Vergata within the CRUICARE Agreement.

Open Access This article is licensed under a Creative Commons Attribution 4.0 International License, which permits use, sharing, adaptation, distribution and reproduction in any medium or format, as long as you give appropriate credit to the original author(s) and the source, provide a link to the Creative Commons licence, and indicate if changes were made. The images or other third party material in this article are included in the article's Creative Commons licence, unless indicated otherwise in a credit line to the material. If material is not included in the article's Creative Commons licence and your intended use is not permitted by statutory regulation or exceeds the permitted use, you will need to obtain permission directly from the copyright holder. To view a copy of this licence, visit http://creativecommons.org/licen ses/by/4.0/.

\section{References}

Acharya, V., Hahn, M., \& Kehoe, C. (2013). Corporate governance and value creation: Evidence from private equity. The Review of Financial Studies, 26(2), 368-402. https://doi.org/10.1093/rfs/hhs117.

Achleitner, A.-K., Betzer, A., \& Gider, J. (2010). Do corporate governance motives drive hedge fund and private equity fund activities? European Financial Management, 16(5), 805-828. https://doi.org/10. 1111/j.1468-036x.2010.00557.x.

Achleitner, A.-K., Betzer, A., Goergen, M., \& Hinterramskogler, B. (2013). Private equity acquisitions of continental European firms, the impact of ownership and control on the likelihood of being taken private. European Financial Management, 19(1), 72-107. https://doi.org/10.1002/eufm.569.

Aldatmaz, S., \& Brown, G. W. (2019). Private equity in the global economy: Evidence on industry spillovers, UNC Kenan-Flagler Research Paper No. 2013-9, 29th Annual Conference on Financial Economics \& Accounting 2018. https://doi.org/10.1016/j.jcorpfin.2019.101524

Allen, J., \& Phillips, G. (2000). Corporate equity ownership, strategic alliances, and product market relationships. The Journal of Finance, 55(6), 2791-2815. https://doi.org/10.1111/0022-1082.00307.

Altman, E. I. (1983). Corporate financial distress. A complete guide to predicting, avoiding, and dealing with bankruptcy. Wiley Interscience, Wiley.

Altman E. I., Iwanicz-Drozdowska, M., Laitinen, E. K., \& Suvas, A. (2014). Distressed firm and bankruptcy prediction in an international context, a review and empirical analysis of Altman's Z-Score Model. Working paper. https://doi.org/10.2139/ssrn.2536340

Andrade, G., \& Kaplan, S. (1998). How costly is financial (not economic) distress? Evidence from highly leveraged transactions that became distressed. The Journal of Finance, 53(5), 1443-1493. https:// doi.org/10.1111/0022-1082.00062.

Barney, J. B. (1991). Firm resources and sustained competitive advantage. Journal of Management, 17(1), 99-120. https://doi.org/10.1177/014920639101700108.

Bain \& Company Inc. (2018). Global private equity report 2018. https://www.bain.com/insights/globalprivate-equity-report-2018/

Bloom, N., Sadun, R., \& Van Reenen, J. (2015). Do private equity owned firms have better management practices? American Economic Review, 105(5), 442-446. https://doi.org/10.1257/aer.p20151000.

Boucly, Q., Sraer, D., \& David, T. (2011). Growth LBOs. Journal of Financial Economics, 102(2), 432453. https://doi.org/10.1016/j.jfineco.2011.05.014.

Boucly, Q., Sraer, D., \& Thesmar, D. (2009). Leveraged buyouts-evidence from French deals. The global economic impact of private equity report, 47-64.

Bruining, H., Verwaal, E., \& Wright, M. (2013). Private equity and entrepreneurial management in management buy-outs. Small Business Economics, 40(3), 591-605. https://doi.org/10.1007/ s11187-011-9386-8.

Carter, D. A., Simkins, B. J., \& Simpson, W. G. (2003). Corporate governance, board diversity, and firm value. The Financial Review, 38(1), 33-53. https://doi.org/10.1111/1540-6288.00034.

Coles, J., Daniel, N., \& Naveen, L. (2008). Boards, does one size fit all? Journal of Financial Economics, 87(2), 329-356. https://doi.org/10.1016/j.jfineco.2006.08.008. 
Cornelli, F., \& Karakaş, O. (2008). Private equity and corporate governance, do LBOs have more effective boards? The Global Economic Impact of Private Equity Report. https://doi.org/10.2139/ssrn. 1102467.

Cressy, R., Munari, F., \& Malipiero, A. (2007). Playing to their strengths? Evidence that specialization in the private equity industry confers competitive advantage. Journal of Corporate Finance, 13(4), 647-669. https://doi.org/10.1016/j.jcorpfin.2007.04.007.

Cumming, D., Siegel, D., \& Wright, M. (2007). Private equity, leveraged buyouts and governance. Journal of Corporate Finance, 13(4), 439-460. https://doi.org/10.1016/j.jcorpfin.2007.04.008.

Davis, S. J., Haltiwanger, J., Handley, K., Jarmin, R., Lerner, J., \& Miranda, J. (2014). Private equity, jobs, and productivity. American Economic Review, 104(12), 3956-3990. https://doi.org/10.1257/ aer.104.12.3956.

Davis, J. H., Schoorman, F. D., \& Donaldson, L. (1997). Toward a Stewardship Theory of Management. Academy of Management Review, 22(1), 20-47. https://doi.org/10.5465/amr.1997.9707180258.

Desbrières, P., \& Schatt, A. (2002). The impacts of LBOs on the performance of acquired firms, the French Case. Journal of Business Finance and Accounting, 29(5-6), 695-729. https://doi.org/10. 1111/1468-5957.00447.

Di Pietra, R., Grambovas, C. A., Raonic, I., \& Riccaboni, A. (2008). The effects of board size and 'busy' directors on the market value of Italian companies. Journal of Management \& Governance, 12(1), 73-91. https://doi.org/10.1007/s10997-008-9044-y.

Duchin, R., Matsusaka, J. G., \& Ozbas, O. (2010). When are outside directors effective? Journal of Financial Economics, 96(2), 195-214. https://doi.org/10.1016/j.jfineco.2009.12.004.

Ernst \& Young. (2018). 2018 Global Private Equity Survey. https://assets.ey.com/content/dam/ey-sites/ ey-com/en_gl/topics/private-equity/private-equity-pdfs/2018-global-private-equity-survey-infog raphics-booklet.pdf?download

Fama, E. F., \& Jensen, M. C. (1983). Agency problems and residual claims. Journal of Law and Economics, 26(June), 327-349. https://doi.org/10.1086/467038.

Finkelstein, S., \& Mooney, A. C. (2003). Not the usual suspects, how to use board process to make boards better. Academy of Management Perspectives, 17(2), 101-113. https://doi.org/10.5465/ame.2003. 10025204.

Gong, J. J., \& Wu, S. Y. (2011). CEO turnover in private equity sponsored leveraged buyouts. Corporate Governance An International Review, 19(3), 195-209. https://doi.org/10.1111/j.1467-8683.2010. 00834.x

Harford, J., \& Kolasinski, A. (2013). Do private equity returns result from wealth transfers and shorttermism? Evidence from a comprehensive sample of large buyouts. Management Science, 60(4), 888-902. https://doi.org/10.1287/mnsc.2013.1790.

Hotchkiss, E. S., Strömberg, P., \& Smith, D. C. (2014). Private equity and the resolution of financial distress. Working paper, Stockholm School of Economics.

Hoskisson, R. E., Shi, W., Yi, X., \& Jin, J. (2013). The evolution and strategic positioning of private equity firms. Academy of Management Perspectives, 27(1), 22-38. https://doi.org/10.5465/amp. 2012.0131.

Jensen, M. C. (1993). The modern industrial revolution, exit, and the failure of internal control systems. The Journal of Finance, 48(3), 831-880. https://doi.org/10.1111/j.1540-6261.1993.tb040 22.x.

Jensen, M. C., \& Meckling, W. H. (1976). Theory of the firm, managerial behavior, agency costs and ownership structure. Journal of Financial Economics, 3(October), 305-360. https://doi.org/10. 1016/0304-405x(76)90026-x.

Kaplan, S., \& Sensoy, B. A. (2014). Private equity performance: A survey. Annual Review of Financial Economics, 7(1), 597-614. https://doi.org/10.1146/annurev-financial-111914-041858.

Kaplan, S., \& Strömberg, P. (2009). Leveraged buyouts and private equity. Journal of Economic Perspectives, 23(1), 121-146. https://doi.org/10.1257/jep.23.1.121.

Klein, P. G., Chapman, J. L., \& Mondelli, M. P. (2013). Private equity and entrepreneurial governance: Time for a balanced view. Academy of Management Perspectives, 27(1), 39-51. https://doi. org/10.5465/amp.2012.0132.

Korteweg, A., \& Sorensen, M. (2017). Skill and luck in private equity performance. Journal of Financial Economics, 124(3), 535-562. https://doi.org/10.1016/j.jfineco.2017.03.006.

Leiblein, M. J. (2011). What do resource- and capability-based theories propose? Journal of Management, 37(4), 909-932. https://doi.org/10.1177/0149206311408321. 
Meuleman, M., Amess, K., Wright, M., \& Scholes, L. (2009). Agency, strategic entrepreneurship, and the performance of private equity-backed buyouts. Entrepreneurship, Theory and Practice, 33(1), 213-239. https://doi.org/10.1111/j.1540-6520.2008.00287.x.

Meuleman, M., Wilson, N., Wright, M., \& Neckebrouck, J. (2014). Entrepreneurial buyouts and financial distress, a multiple agency perspective. Frontiers of Entrepreneurship Research, 34(2), 80-94. Available at: http://digitalknowledge.babson.edu/fer/vol34/iss $2 / 5$

Millson, R., \& Ward, M. (2005). Corporate governance criteria as applied in private equity investments. South African Journal of Business Management, 36(1), 73-85. https://doi.org/10.4102/ sajbm.v36i1.622.

Nikoskelainen, E., \& Wright, M. (2007). The impact of corporate governance mechanisms on value increase in leveraged buyouts. Journal of Corporate Finance, 13(4), 511-537. https://doi.org/10. 1016/j.jcorpfin.2007.04.002.

Nordström, L. (2015). A long-term perspective on private equity ownership. Ratio Working Paper No. 269. https://doi.org/10.2139/ssrn.877233

Nyberg, A. J., Moliterno, T. P., Hale, D., Jr., \& Lepak, D. P. (2014). Resource-based perspectives on unit-level human capital: A review and integration. Journal of Management, 40(1), 316-346. https://doi.org/10.1177/0149206312458703.

Preqin. (2018). 2018 Preqin global private equity \& venture capital report, Preqin publications. https://docs.preqin.com/reports/2018-Preqin-Global-Private-Equity-Report-Sample-Pages.pdf

Rosenbaum, P., \& Rubin, D. (1983). The central role of the propensity score in observational studies for causal effects. Biometrika, 70(1), 41-55. https://doi.org/10.1093/biomet/70.1.41.

Scellato, G., \& Ughetto, E. (2013). Real effects of private equity investments, evidence from European buyouts. Journal of Business Research, 66(12), 2642-2649. https://doi.org/10.1016/j.jbusr es.2012.06.001.

Siegel, D., Wright, M., \& Filatotchev, I. (2011). Private equity, LBOs, and corporate governance, international evidence. Corporate Governance, an International Review, 19(3), 185-194. https:// doi.org/10.1111/j.1467-8683.2010.00842.x.

Terjesen, S., Couto, E. B., \& Francisco, P. M. (2016). Does the presence of independent and female directors impact firm performance? A multi-country study of board diversity. Journal of Management \& Governance, 20(3), 447-483. https://doi.org/10.1007/s10997-014-9307-8.

Tykvová, T., \& Borell, M. (2012). Do private equity owners increase risk of financial distress and bankruptcy? Journal of Corporate Finance, 18(1), 138-150. https://doi.org/10.1016/j.jcorpfin.2011.11. 004.

Wilson, N., \& Wright, M. (2013). Private equity, buy-outs and insolvency risk. Journal of Business Finance and Accounting, 40(7), 949-990. https://doi.org/10.1111/jbfa.12042.

Wright, M., Amess, K., Weir, C., \& Girma, S. (2009a). Private equity and corporate governance, retrospect and prospect. Corporate Governance, an International Review, 17(3), 353-375. https://doi. org/10.1111/j.1467-8683.2009.00744.x.

Wright, M., Gilligan, J., \& Amess, K. (2009b). The economic impact of private equity, what we know and what we would like to know. Venture Capital, an International Journal of Entrepreneurial Finance, 11(1), 1-21. https://doi.org/10.1080/13691060802151887.

Wright, M., Hoskisson, R. E., Busenitz, L. W., \& Dial, J. (2000). Entrepreneurial growth through privatization, the upside of management buyouts. The Academy of Management Review, 25(3), 591-601. https://doi.org/10.5465/amr.2000.3363522.

Wright, M., Wilson, N., Robbie, K., \& Ennew, C. (1996). An analysis of management buy-out failure. Managerial and Decision Economics, 17(1), 57-71. https://doi.org/10.1002/(sici)10991468(199601)17:1\%3c57::aid-mde734\%3e3.0.co;2-a.

Publisher's Note Springer Nature remains neutral with regard to jurisdictional claims in published maps and institutional affiliations.

Vladimiro Marini gained a Ph.D. in Banking and Finance at University of Rome "Tor Vergata". Currently, he works as data scientist at Banca Etica SCPA. 
Massimo Caratelli is Associate Professor of Banking and Finance in the Department of Business Studies at Roma Tre University.

Gian Paolo Stella gained a Ph.D. in Banking and Finance at University of Rome "Tor Vergata". Currently, he works as Adjunct Professor in Corporate Finance and Risk Management at Link Campus University.

Ilaria Barbaraci has studied at University of Bologna. Recently she did an internship as assistant researcher in Hannover at Fraunhofer IWES. 